\title{
Union Citizenship for UK Citizens
}

\author{
Glyn Morgan
}

In the wake of the Brexit vote, Floris de Witte's defence of citizenship-based freedom of movement is as important as it is timely. In linking movement to citizenship, as de Witte notices, those who move have a secure status in their new country. In any member state, the new arrival is not a foreigner, not a guest, not someone who has to apologize for being there, but a citizen whose rights are guaranteed by the EU. No one can say: 'you don't belong here.' And if they did; the response would be: 'I have the same rights as you to live and work anywhere in the EU.'

Now with Brexit, UK citizens will lose freedom of movement, and Europeans resident in Britain will lose the protection afforded by Union citizenship. More worrying still, Brexit threatens to unravel the postwar achievements of European integration. If the UK prospers in the immediate aftermath of Brexit, other countries might follow. A Europe of nation-states will be the outcome. The idea of a unified European polity ${ }^{1}$ powerful enough to defend itself and project its values abroad will be lost.

The EU must act to ensure that Brexit is a failure. It can do this by crafty deployment of a carrot and stick strategy. The stick should come in the form of refusing the UK any privileged access to the Single Market without accepting freedom of movement. No 'passporting' for the UK financial services industry - a key component of the British economy - should be allowed. US and other foreign banks should be forced to relocate their headquarters to an EU financial centre. The EU should make crafty use of nontrade barriers to hinder the exports of British manufacturers. If the UK wants out of the Customs Union, then the EU should monitor in fine-grained detail, a slow and cumbersome process, the foreign component of UK exports. British visitors to the Continent should be required to attain expensive visas.

The carrot comes in the form of citizenship-based freedom of movement. One step in the right direction would be for the EU to move towards a form of Union citizenship unmediated by any prior national citizenship. At the

Morgan, G. (2007), The Idea of a European Superstate Public Justification and European Integration, $2^{\text {nd }}$ edition. Princeton: Princeton University Press. 
moment, people in Europe are offered only the status of being hyphenated Europeans (French-European; German-European, Italian-European etc.) rather than Europeans as such. Brexit provides an opportunity here. Sixteen million UK electors voted to remain in the EU. These people will now lose even their meagre hyphenated status and become, for the most part, reluctant national citizens of a country in the grip of populist nativism. ${ }^{2}$ The EU can rescue pro-Europeans from their fallen state by offering them Union citizenship -European passports unmediated by national citizenship, which will provide them with the right to live and work anywhere in Europe. Many UK citizens will jump at the opportunity.

One difficulty with this proposal is that it offers UK citizens an advantage not currently extended to other Europeans, including, most worryingly, those now living in Britain who are threatened with losing their right to live and work there. To address this problem, the offer of unmediated European citizenship for Brits could be made conditional on Britain offering current EU citizens full national citizenship in Britain. Doubtless, the current Conservative Government will reject this suggestion. Alternatively, the offer of EU citizenship for Brits could be made contingent on certain forms of equitable treatment for current EU citizens resident in Britain. Such conditional offers from the EU will further encourage the pro-European British citizens to fight for the rights of current EU citizens in Britain. Any future British government that might wish to play fast and loose with such people will face the ire of the pro-European British eagerly awaiting the opportunity to acquire EU citizenship.

More generally, it might be objected that this citizenship proposal rewards secessionists like Britain by offering UK citizens a desirable form of unmediated citizenship. Surely, this might simply encourage other European member states to follow Britain out of Europe. This objection can be met by charging UK citizens a fee, say $€ 10,000$, to acquire European Citizenship. This policy will not only provide the funds to finance the Citizenship Office, which will have to be created de novo, but will discourage countries from thinking that they can secede from Europe while enjoying the full benefits of membership. If $€ 10,000$ is too much for some people, they could be offered European citizenship for free in return for working on pro-EU projects, which could be arranged and overseen by the new

2 'Polish men attacked in "hate crime" hours after murdered Pole's vigil in Harlow', Independent, 4 September 2016, available at http://www.independent. co.uk/news/uk/crime/polish-hate-crime-harlow-essex-attacked-murdered-vigilarek-j-wik-brexit-a7225166.html. 
Citizenship Office. Alternatively, UK citizens could acquire Union Citizenship only if they agree to pay a small tax indexed to their salary. Needless to say, these are bold and radical proposals, which those familiar only with mediated member-state based citizenship will take time to accept.

Admittedly, this proposal does nothing to address the concerns of Rainer Bauböck who worries about the divide between the mobile and the immobile citizens. Indeed, in some ways this proposal further exacerbates the division between these two groups. Nor does it solve Sarah Fine's concerns about 'the growing divide between European citizens and the people they want to keep out.' The proposal does, however, connect with Kieran Oberman's appeal to John Stuart Mill. Many of Mill's political writings are the works of a partisan. They are written to and for progressives who find themselves in a society where they are a minority. Mill was forever coming up with clever institutional wheezes and innovative policies that would move the cause of progress along. Knowing how to overcome setbacks is a necessary part of this project. Citizenship for pro-European Brits does not solve all of the problems that now plague post-Brexit Europe. But it offers rewards for people who need encouragement and are the most likely to become the agents of change needed to address the more serious global problems raised by Fine, Oberman, and others.

Open Access This chapter is licensed under the terms of the Creative Commons Attribution 4.0 International License (http://creativecommons.org/licenses/by/4.0/), which permits use, sharing, adaptation, distribution and reproduction in any medium or format, as long as you give appropriate credit to the original author(s) and the source, provide a link to the Creative Commons license and indicate if changes were made.

The images or other third party material in this chapter are included in the chapter's Creative Commons license, unless indicated otherwise in a credit line to the material. If material is not included in the chapter's Creative Commons license and your intended use is not permitted by statutory regulation or exceeds the permitted use, you will need to obtain permission directly from the copyright holder. 